The 2007-2008 financial crisis: Is there evidence of disaster myopia? 


\section{GATE Groupe d'Analyse et de Théorie Économique Lyon-St Étienne}

93, chemin des Mouilles 69130 Ecully - France

Tel. +33 (0)4 72866060

Fax $+33(0) 472866090$

6, rue Basse des Rives 42023 Saint-Etienne cedex 02 - France

Tel. +33 (0)4 77421960

Fax. $+33(0) 477421950$

Messagerie électronique / Email : gate@gate.cnrs.fr

Téléchargement / Download : http://www.gate.cnrs.fr - Publications / Working Papers 


\title{
The 2007-2008 financial crisis: \\ Is there evidence of disaster myopia?
}

July 13, 2011

\author{
Camille Cornand and Céline Gimet*
}

\begin{abstract}
The disaster myopia hypothesis is a theoretical argument that may explain why crises are a recurrent event. Under very optimistic circumstances, investors disregard any relevant information concerning the increasing degree of risk. Agents' propensity to underestimate the probability of adverse outcomes from the distant past increases the longer the period since that event occurred and at some point the subjective probability attached to this event reaches zero. This risky behaviour may contribute to the formation of a bubble that bursts into a crisis. This paper tests whether there is evidence of disaster myopia during the recent episode of financial crisis in the banking sector. Its contribution is twofold. First, it shows that the 2007 financial crisis exhibits disaster myopia in the banking sector. And second, it identifies macro and specific determinant variables in banks' risk taking since the beginning of the years 2000 .
\end{abstract}

JEL Classification: G01, G21, C23.

Key-words: disaster myopia, financial crisis, banks, risk taking dynamics, GMM.

\section{Introduction}

The disaster myopia hypothesis has been introduced by Guttentag and Herring (1986) to explain why crises are a recurrent event. Under very optimistic circumstances, investors disregard any relevant information concerning the increasing degree of risk. Agents' propensity to underestimate the probability of adverse outcomes from the distant past increases the longer the period since that event occurred and at some point the subjective probability attached to this event reaches zero. This paper tests whether there is evidence of disaster myopia during the recent episode of financial crisis in the banking sector.

The financial crisis of 2007 is generally attributed to a number of factors associated with the housing and credit markets. Macroeconomic factors such as monetary policy, international trade imbalances, and the lack of government regulation are as well considered to have played a role in the

\footnotetext{
${ }^{*}$ Camille Cornand - BETA CNRS and Strasbourg University - 61, avenue de la forêt noire - 67085 Strasbourg cedex France; email: cornand@cournot.u-strasbg.fr. Céline Gimet - University of Lyon, Lyon, F-69003, France ; University of Lyon 2, Lyon, F-69007, France; CNRS, GATE Lyon St Etienne, Ecully, F-69130, France; email: gimet@gate.cnrs.fr. We are thankful to André Cartapanis and Charles Laitong for useful comments.
} 
crisis. Without denying the effects of the aforementioned factors, this paper suggests that current financial crisis also has its roots in the disaster myopia of market participants and especially banks.

Disaster myopia has been used to explain the LDC debt crisis, the US savings and loans debacle and various commercial property crises. ${ }^{1}$ Although Haldane (2009) and Herring (2008) interpret the recent financial crisis as a consequence of disaster myopia and argue that disaster myopia has been one of its predominating factors, there is no empirical test of this hypothesis. In this paper, we precisely empirically test whether the 2007 illiquidity shock can be considered as a myopiainduced disaster by analyzing the (decreasing) risk perception of banks over the period preceding the occurrence of the crisis.

To measure disaster myopia, we focus on risk taking dynamics. Bank risk-taking may be measured by several manners in the literature. First, as in Saunders, Strock, and Travlos (1990), Esty (1998), and Grossman and Imai (2010), among others, one can use the volatility of share prices (this corresponds to computing the standard deviation of monthly changes in share prices for a given year for each bank, which is matched up with annual data on bank liability characteristics). ${ }^{2}$ Three other measures of risk-taking from bank balance sheets are also used: the ratio of loans to total assets, the ratio of cash to total assets, and the rate of growth of assets. The assumption is that loans are riskier and less liquid — and that cash is less risky and more liquid — than other balance sheet assets, primarily securities. Banks with substantial contingent liabilities should have a smaller proportion of their assets in loans and a larger proportion of their assets in cash than limited liability banks if the risk-reducing incentive of contingent liability is strong. Risk-taking can also be measured by the rate at which a bank's assets expand in a given year under the theory that, all other things being equal, banks that engage in riskier activities will grow more rapidly than banks behaving in a more conservative manner (Calomiris 1990, Grossman 2001, 2007).

In this paper, we consider the maturity mismatch in banks' balance sheets as an indicator of risk taking in the banking sector. ${ }^{3}$ Indeed, as Diamond and Rajan (2009) and Fahri and Tirole (2009, p. 2) suggest, the current crisis "is one of wide-scale maturity mismatch". More precisely, we look at the distortions in the maturities in banks' balance sheets by considering the share of liquid assets compared to long term liabilities. Maturity mismatches accepted by banks make them vulnerable to acute liquidity risk. We focus on the banking sector as this problem was even more acute because of the interaction between accounting rules and prudential norms (Basel II). During economic

\footnotetext{
${ }^{1}$ For example, Guttentag and Herring (1986) and Herring (1999).

${ }^{2}$ This measure has several limitations. First, some banks are privately owned, and thus their shares are not traded. Second, even when banks are publicly traded, shares are not transacted every month, presumably because these shares are not especially liquid.

${ }^{3}$ Note here that maturity mismatch is not used in its traditional sense. Chang and Velasco (1998), Goldfajn and Valdes (1999) and others have argued that foreign asset-liability mismatches in the East Asian economies was an "inevitable" consequence of international financial intermediation. See also Bird and Rajan (2001). Here, we simply consider that if banks perceived a low risk, they had a tendency to have a wide maturity mismatch, while when they perceived high risk on the market, they tended to reduce the mismatch.
} 
slowdowns, default rates increase, asset prices decrease, which generates losses for banks that reduce their capital. Simultaneously because of prudential norms, the requirements for capital increase. Therefore, as capital is reduced and the need for capital is increased, there necessarily is a contraction in credit offer.

In terms of methodology, we use a Generalized Method of Moments (GMM) model as the study of disaster myopia refers to a dynamic process. Indeed, we study to what extent the lagged values of the risk taking variables influence the current value of this variable. The GMM shows first that risk taking in period $t$ is influenced by risk taking in period $t-1$ at least, and second that there is a set of variables -specific to the banking sector as the size, profitability, vulnerability, but also to the economic and financial environment- that determine risk taking. The main result of the paper is that the disaster myopia hypothesis is relevant to understand the current financial crisis. Regressions reinforces our results as they show that risk taking increases from the mid 2000's and as time goes on until the year 2007. We identify a break in 2007 and a decrease in risk taking in 2008 and 2009.

The article is organized as follows. The next section describes the considered conceptual framework of disaster myopia. Section III presents the data, the methodology used to test the theory and justifies the choice of variables. Section IV establishes test results. Section V discusses the policy implications of evidence of disaster myopia and section VI concludes.

\section{Conceptual framework: the disaster myopia hypothesis}

Guttentag and Herring ${ }^{4}$ analyze the decision making process of investors under uncertainty. Disaster myopia is a situation in which agents tend to underestimate the probability of adverse outcomes. Such a behaviour is especially overriding for small probability events from a distant past. The authors use cognitive psychology ${ }^{5}$ to build their reasoning. According to this approach, economic agents base their decisions rules on rough heuristic or rules of thumb. The closest conceptual approach is that of Herring (1998); in this section, we present a simplified and slightly modified version of it. We first describe the context, before presenting the disaster myopia hypothesis and the institutional factors that may give rise to such a behavior. This framework enables us to state our tested hypotheses.

\subsection{Uncertainty, objective and subjective risk probabilities}

In an uncertain environment, individuals use subjective probabilities. A subjective probability is a personal judgment concerning the likelihood of the occurrence of a particular event. Individuals do not use precise computation but base their judgment on a reasonable assessment. A person's subjective

\footnotetext{
${ }_{5}^{4}$ See Guttentag and Herring $(1984,1986)$, Herring $(1998,1999)$ and Herring and Wachter $(2002)$.

${ }^{5}$ It is well-established in cognitive psychology that economic agents have a tendency to base decision rules around rough heuristics or rules of thumb. For experimental evidence, see Kahneman et al. (1982).
} 
probability of an event describes his/her degree of belief in the event. There is no formal calculation, but past experiences are very important to form these probabilities. At the opposite, objective probabilities estimate the occurrence of an event based on a recorded observation, rather than a subjective estimate.

On the one hand, the "availability heuristic" -which refers to the ease with which a decision maker can imagine that an event will occur- rests on the fact that the longer the period since an event occurred, the lower the subjective probability attached to it.

On the other hand, below a certain threshold, this subjective probability sets at zero. This is the "threshold heuristic": it exacerbates the bias toward the underestimation of shock probabilities. More precisely, threshold heuristic is the rule of thumb by which decision markers devote scarce management time to analyze these probabilities.

\subsection{Disaster myopia}

The ease with which a decision maker can imagine that an event will occur rests on the fact that the longer the period since an event occurred, the lower the subjective probability attached to it (Figure 1).

Figure 1. The disaster myopia hypothesis

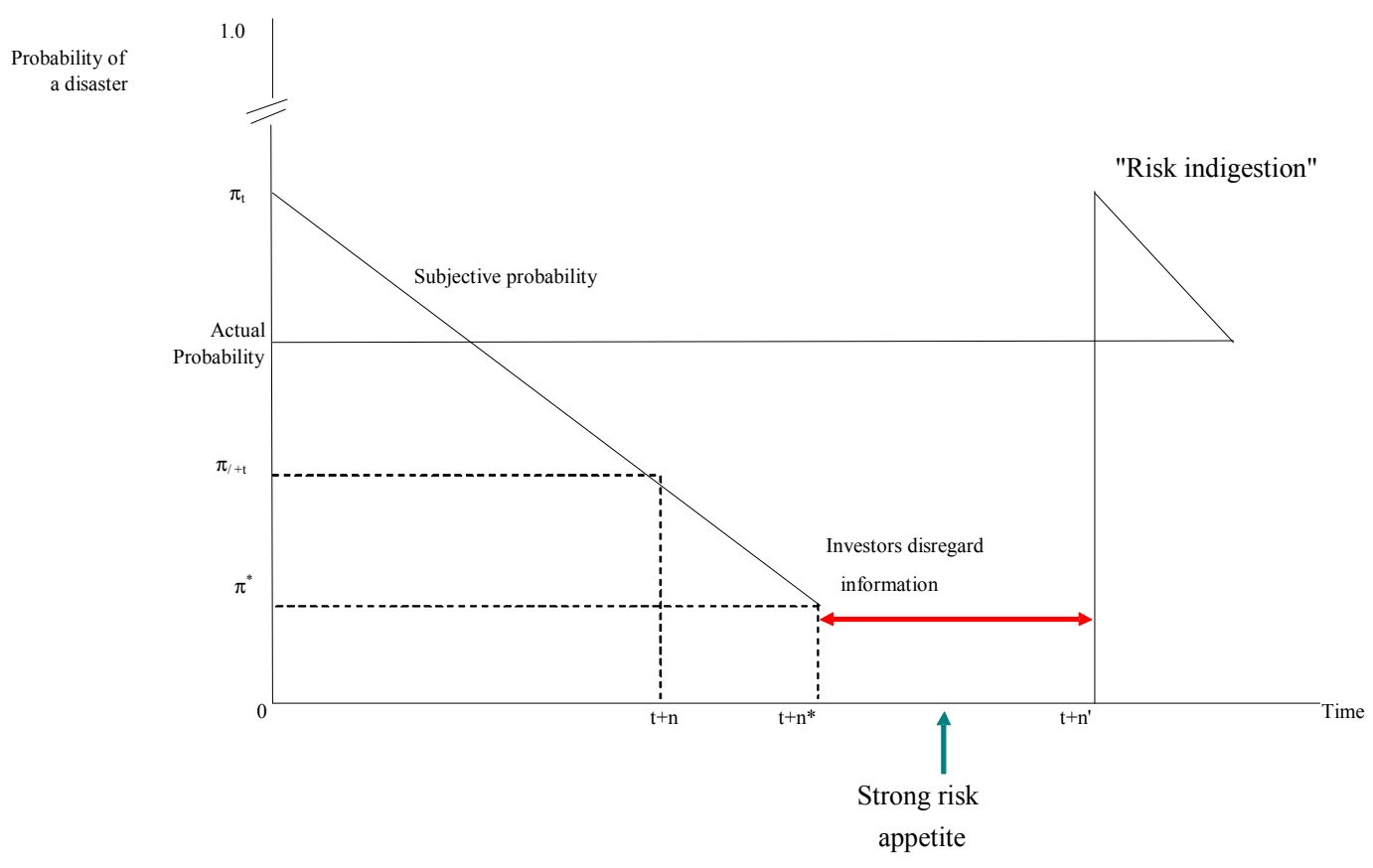

Source: adapted from Herring (1998).

If the period without major shocks is sufficiently long, then subjective probabilities are validated over time and converge toward fully-rational objective probabilities. In such an environment, investors completely disregard information, they have a strong risk appetite since they believe that the 
probability that a major negative shock $^{6}$ occur is near zero. We may enter a phase of 'risk indigestion' (Allegret and Cornand, 2011): a crisis occurs and subjective probabilities start to be very high again, higher than the objective ones. As noted by Haldane (2009, p. 6), 'it is perhaps no coincidence that the last three truly systemic crises - October 1987, August 1998, and the credit crunch which commenced in 2007 - were roughly separated by a decade. Perhaps ten years is the threshold heuristic for risk managers'.

\subsection{Institutional factors}

According to Herring (2008), institutional factors from the "Golden Decade" -the period referring to the years from 1998 to 2007- encouraged disaster myopia during the 2007-2008 financial crisis.

First, managerial accounting systems favour activities subject to low-frequency losses. Many risk management models developed within the private sector during the Golden Decade could have induced disaster myopia. According to Haldane (2009), these models were often data hungry, improvements in data and IT technology feeding them with vast, high-frequency datasets, providing ample degrees of freedom for modellers, enabling them to devise risk frameworks which were very precisely calibrated in-sample. 'The sample in question was, with hindsight, most unusual from a macroeconomic perspective. The distribution of outcomes for both macroeconomic and financial variables during the Golden Decade differed very materially from historical distribution' (Haldane, 2009, p. 7).

Second, underestimation of risk has consequences for the risks facing both individual firms and for the system as a whole. For the system as a whole, one way of illustrating the consequences of underestimating risk is to translate it into "fair value" insurance premia. Haldane (2009, p. 9) illustrates risk under pricing on a dramatic scale: 'The degree of under-pricing of risk is large and is larger for options designed to protect against tail risks (lower strike prices). For at-the-money options on UK equities, the insurance premium would have been under-priced by around 45\%; for options well out-of-the-money-say, 50\% below equity prices at the time-the mis-pricing would have been nearer $90 \%$.

Among the other institutional factors mentioned by Herring (2008), we can find: the recognition of fees upfront as income, the bonuses tied to current revenues, the high job mobility among risk takers, the intense competition in financial markets that drives out participants who are not disaster myopic and the appearance of high profitability attracting new entrants. For more details, see Herring (2002) who already identified these institutional factors as a potential source of disaster myopia.

\footnotetext{
${ }^{6}$ This negative shock may even be endogenous, attributed to their own risky behaviour that increases the fragility of the system.
} 
2.4. Hypotheses to be tested: disaster myopia in the banking sector

It is particularly relevant to identify bank's myopia not only because the banking sector was at the core of the recent financial disaster but also because exposures in this sector grow so large that they can jeopardize the financial system (for systemic risk analysis during the 2007 financial crisis, see for instance Bullard et al. (2009)). Identifying and limiting the impact of the banking sector's disaster myopia is helpful to limit consequences for the system as a whole. So based on the former conceptual framework, we propose to test the following two hypotheses:

(i) the influence of the macroeconomic and financial context on the one hand and banking sector related financial variables on the other hand on banks' risk taking dynamics;

(ii) the existence of disaster myopia in the banking sector during the recent financial crisis.

\section{Testing the disaster myopia hypothesis: the empirical model}

This section presents the database constructed owing to Bankscope, IFS and OECD data. Our study is based on a sample of 7,360 banks from 151 countries over the period 2002-2009. After describing the methodology used to test the disaster myopia hypothesis, the choice of macroeconomic and banking variables is justified.

\subsection{The GMM model}

In a first time, a GMM estimator on a large sample and small periods is used in order to underline the dynamic of the bank risk-taking during the 2000's. In a second step, a regression in cross-section and in panel focuses on the 2007 episode. Its purpose is to highlight the presence of disaster myopia phenomenon during the 2007 crisis.

As the study of disaster myopia refers to a dynamic process, we must study to what extent the lagged values of the indicator of risk taking and the initial banking, financial and real conditions influence the current value of risk taking. The starting point for this analysis is a simple regression using the endogenous lagged variable as well as the explanatory variables in $t$ and $t-1$. When the ordinary least squares estimator is used for this purpose, there is a problem of correlation between the explanatory variables and the error term due to individual effects, which then gives rise to an upward bias. The within estimator enables us to eliminate this problem by integrating fixed effects and allows us to take into account institutions specificities. Nevertheless, in the context of our analysis, there is a limited number of periods, which produces a significant correlation between the dependent lagged variable and the error term. Therefore, the use of this estimator is also biased, but in the opposite direction. Given the problems encountered by these two methods, it is advisable to use a dynamic model allowing for the introduction of instrumental variables. These variables are correlated to the 
lagged value of the endogenous variable and not with the error term of the model (for $t=2,3, \ldots, T$ ), which solves our problem. The effects of the explanatory exogenous variables on the explained variable can then be interpreted (Arellano and Bond, 1991). Hence, the GMM seems to be the best adapted method for our estimation. It should be noted that Blundell and Bond's (1998) Monte Carlo simulations showed that the system GMM estimator is more efficient than the first-differenced one. Indeed when the number of instruments is small and when there is a finite sample, the first-differenced GMM estimator is biased. It should also be noted that in order to validate the use of a GMM model, the estimated coefficient of the dependent lagged variable must be larger than that of the within estimator and smaller than that of the OLS estimator. Our model can be written as follows:

$$
y_{i, t}=\alpha y_{i, t-1}+\beta \sum_{t=0}^{n} X_{i, t-n}+u_{i}+v_{i, t}
$$

with $i=1, \ldots, 7,360$, and $t=2002, \ldots, 2009$, where $y_{i, t-1}$ represents the dependent lagged variable for each institution in the period $t-1, X_{i, t-n}$ the set of explanatory lagged variables, $u_{i}$ the specific individual effect for each institution, $v_{i, t}$ the specific shock at each period and on each institution and where $E\left[x_{i, t}\left(u_{i}+v_{i, t}\right)\right]=0$.

3.2. Data and justification of the choice of variables

The dependent variable is a measure of risk taking defined by the ratio:

$$
\text { risk }=\frac{\text { liquid assets }(\text { thousand USD) }}{\text { total liabilities }- \text { short term fundings (thousand USD) }} \text {. }
$$

Taking the risk variable one and more periods lagged enables us to show the persistence of risk taking over time.

Concerning the explanatory variables, we distinguish between the banking sector and other macro variables, which are described in Table 1. 
Table 1. Synthesis and definition of the model's explanatory variables.

\begin{tabular}{|c|c|c|c|}
\hline $\begin{array}{l}\text { Explanatory } \\
\text { variable }\end{array}$ & Definition & $\begin{array}{l}\text { Expected } \\
\text { Sign } \\
\end{array}$ & Role of the variable \\
\hline \multicolumn{4}{|c|}{ Global financial and macroeconomic variables (by countries) } \\
\hline prices & $\begin{array}{l}\text { Collateral - } \\
\text { Housing price } \\
\text { growth rate }\end{array}$ & $(+)$ & $\begin{array}{l}\text { Housing prices growth. } \\
\text { Rational bubbles may explain deviations from the } \\
\text { fundamentals and the existence of risk dynamics (Blanchard } \\
\text { and Watson, 1983). }\end{array}$ \\
\hline vol & $\begin{array}{l}\text { Realized } \\
\text { volatility of } \\
\text { the Stock } \\
\text { exchange } \\
\text { index }\end{array}$ & $(-)$ & $\begin{array}{l}\text { Volatility. } \\
\text { Low volatilities may increase incentives for banks to take on } \\
\text { more risk for behavioral, contractual or institutional reasons } \\
\text { (Brunnermeier, 2001, Rajan, 2005). }\end{array}$ \\
\hline$g d p$ & $\begin{array}{l}\text { GDP growth } \\
\text { rate }\end{array}$ & $(+)$ & $\begin{array}{l}\text { Economic growth. } \\
\text { According to the 'paradox of tranquillity' (Minsky, 1982), the } \\
\text { fragilities were masked by the success of the economy and the } \\
\text { economic agents benefit from new growth opportunities. }\end{array}$ \\
\hline intrate & $\begin{array}{l}\text { Monetary } \\
\text { market rate }\end{array}$ & $(-)$ & $\begin{array}{l}\text { Monetary policy. } \\
\text { Low interest rates may influence bank risk-taking (Adrian and } \\
\text { Shin, 2009a, b, Borio and Zhu, 2008). }\end{array}$ \\
\hline region & $\begin{array}{l}\text { Dummy } \\
\text { variable }\end{array}$ & $(+)$ & $\begin{array}{l}=1 \text { for industrialized countries. } \\
\text { Risk taking dynamics may be more pronounced for } \\
\text { industrialized countries which have benefited from emerging } \\
\text { markets' current account surpluses (Bernanke, 2005). }\end{array}$ \\
\hline \multicolumn{4}{|c|}{ Specific banking related variables (by banks) } \\
\hline totkt & $\begin{array}{l}\text { Total capital } \\
\text { ratio }\end{array}$ & $(-)$ & $\begin{array}{l}\text { Prudential. } \\
\text { Bank of International Settlements }\end{array}$ \\
\hline roae & $\begin{array}{l}\text { Return on } \\
\text { average equity }\end{array}$ & $(+)$ & $\begin{array}{l}\text { Return. } \\
\text { High returns may encourage banks to hold equities (Young et } \\
\text { al., 2010). }\end{array}$ \\
\hline netincome $e^{i i}$ & $\begin{array}{l}\text { Net income } \\
\text { USD }\end{array}$ & $(+/-)$ & $\begin{array}{l}\text { Size. } \\
+ \text { Too big to fail: big banks' moral hazard induces them to } \\
\text { take on more risk as they believe in the implicit guarantee of } \\
\text { governments or institutions (Kay (2009), Barrell et al. (2010)). } \\
\text { - Smaller banks have more risky balance sheets (Kashyap and } \\
\text { Stein, 2000). Small banks are pushed towards higher risk- } \\
\text { taking due to fiercer competition (Hakenes and Schnabel, } \\
2005) \text {. }\end{array}$ \\
\hline npl & $\begin{array}{l}\text { Non- } \\
\text { performing } \\
\text { loans } \\
\text { (Impaired } \\
\text { Loans (NPLs)/ } \\
\text { Gross Loans } \\
\text { \%) }\end{array}$ & $(+/-)$ & $\begin{array}{l}\text { Vulnerability, credit risk } \\
\text { The mortgage expansion is accompanied by an increase in } \\
\text { NPLs masked by the house prices growth (Claessens et al., } \\
\text { 2010). }\end{array}$ \\
\hline marketkp & $\begin{array}{l}\text { Market } \\
\text { capitalisation / } \\
\text { shareholders } \\
\text { funds }\end{array}$ & $(+/-)$ & $\begin{array}{l}\text { Market concentration. } \\
\text { Bank risk-taking increases as bank shareholders' power rises } \\
\text { in corporate governance (Laeven and Levine, 2009). }\end{array}$ \\
\hline
\end{tabular}

i. The annual realized volatility is measured by the standard error of the daily returns for each month and thus for each year. The realized volatility is well adapted in the case of high-frequency data. It is an ex-post nonparametric and unbiased volatility estimator (Andersen et al., 2006, 2009) and represents an unbiased indicator that makes it possible to get close to the true volatility and is largely accepted in the asset price volatility modeling and forecasting literature (Chan et al., 2009).

ii. The Netincome variable is taken in logarithm. 


\section{Results}

For the period 2002-2009, the dependent variable perfectly fits with the previous model as testified by the following graphs presented on Figure 2: risk taking decreases in the years following a crisis and increases over time, until reaching the next crisis.

Figure 2. Risk taking over time (2002-2010)

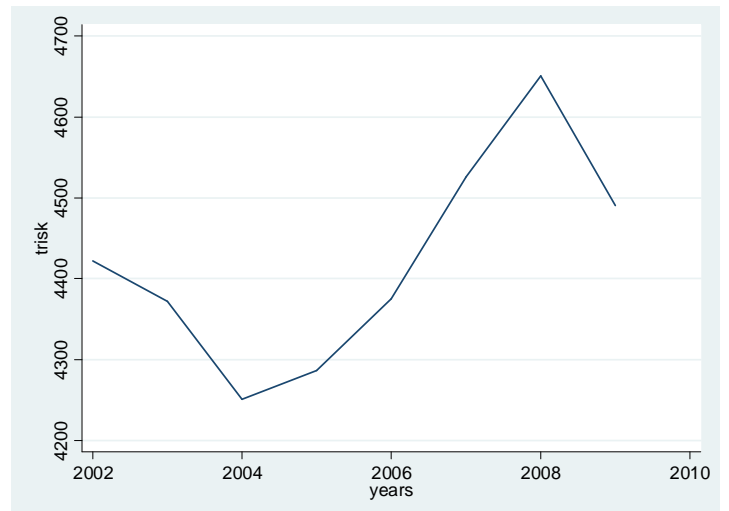

Total risk for all banks of all countries

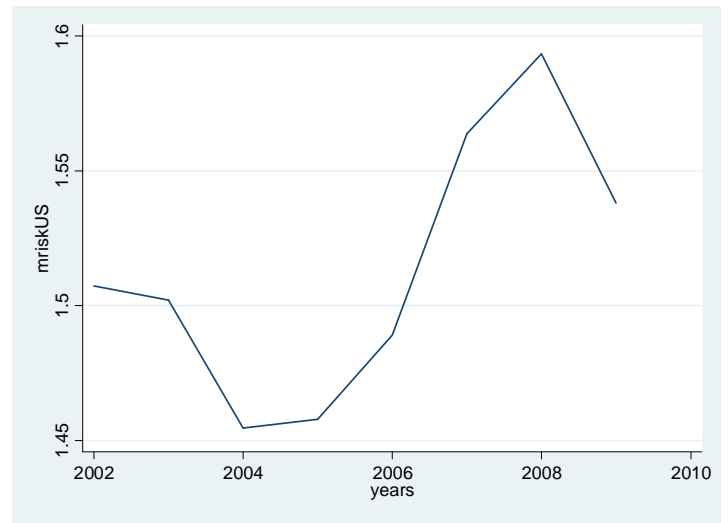

Banks' average risk in the USA

4.1. The GMM estimation over the period 2002-2009

Table 2 presents the GMM system estimation. Different estimations of the same model (OLS, Withingroup and GMM difference) are reported in Appendix B.

The panel is unbalanced in the sense that we have more observations on some banks than on others. The OLS and the Within-group estimators are biased in opposite direction but the use of the GMM estimation is validated because the coefficient of the estimated lagged dependent variable is higher than that of the Within-group estimator and lower than that of the OLS estimator. In all cases, the Hansen tests of over-identifying restrictions validate the instruments used in the model. Furthermore, the Arellano and Bond (1991) tests do not reject the assumption of the absence of second order autocorrelation on the residuals. This study therefore enables us to interpret the estimation's results correctly. Time dummies are included in order to support the assumption that there is no correlation across individuals in the idiosyncratic disturbances. For the dependent endogenous variables lag 2 and deeper are used. The other variables are considered as endogenous and instrumented with lag 2 and deeper except for the time and region dummies that are taken as exogenous. 
Table 2. GMM system results

\begin{tabular}{|c|c|c|c|c|c|c|c|}
\hline & $\begin{array}{c}\text { GMM } \\
\text { Syst }\end{array}$ & $\begin{array}{c}\text { GMM } \\
\text { Syst }\end{array}$ & $\begin{array}{c}\text { GMM } \\
\text { Syst }\end{array}$ & $\begin{array}{l}\text { GMM } \\
\text { Syst }\end{array}$ & $\begin{array}{c}\text { GMM } \\
\text { Syst }\end{array}$ & $\begin{array}{c}\text { GMM } \\
\text { Syst }\end{array}$ & $\begin{array}{c}\text { GMM } \\
\text { Syst }\end{array}$ \\
\hline L.risk & $\begin{array}{c}0.769 * * * \\
{[0.102]}\end{array}$ & $\begin{array}{c}0.822 * * * \\
{[0.057]}\end{array}$ & $\begin{array}{c}0.698 * * * \\
{[0.061]}\end{array}$ & $\begin{array}{c}0.658 * * * \\
{[0.054]}\end{array}$ & $\begin{array}{c}0.823 * * * \\
{[0.062]}\end{array}$ & $\begin{array}{l}0.61 * * * \\
{[0.062]}\end{array}$ & $\begin{array}{c}0.582 * * * \\
{[0.074]}\end{array}$ \\
\hline L2.risk & & & & $\begin{array}{c}0.169 * * * \\
{[0.052]}\end{array}$ & $\begin{array}{c}0.040 \\
{[0.075]}\end{array}$ & $\begin{array}{c}0.15^{* * *} \\
{[0.054]}\end{array}$ & $\begin{array}{l}-0.0063 \\
{[0.069]}\end{array}$ \\
\hline L3.risk & & & & & & $\begin{array}{r}-0.0194 \\
{[0.037]}\end{array}$ & $\begin{array}{c}0.0958^{* *} \\
{[0.043]}\end{array}$ \\
\hline Totkt & & & $\begin{array}{c}-0.00144 * \\
{[0.0008]}\end{array}$ & $\begin{array}{c}-0.0002 \\
{[0.0006]}\end{array}$ & & $\begin{array}{l}-0.0008 \\
{[0.002]}\end{array}$ & \\
\hline Roae & & & & & & $\begin{array}{c}-0.03 * * * \\
{[0.011]}\end{array}$ & \\
\hline Npl & $\begin{array}{c}0.012 \\
{[0.021]}\end{array}$ & $\begin{array}{c}-0.001 \\
{[0.003]}\end{array}$ & & & & & $\begin{array}{c}0.00355^{* *} \\
{[0.002]}\end{array}$ \\
\hline Prices & $\begin{array}{l}0.012^{*} \\
{[0.006]}\end{array}$ & & & & & & \\
\hline Gdp & & $\begin{array}{c}0.028 * * * \\
{[0.009]}\end{array}$ & $\begin{array}{c}-0.00119 \\
{[0.025]}\end{array}$ & $\begin{array}{c}0.026 \\
{[0.025]}\end{array}$ & $\begin{array}{c}0.039 * * * \\
{[0.008]}\end{array}$ & $\begin{array}{c}-0.0172 \\
{[0.0132]}\end{array}$ & \\
\hline L.gdp & & & & & $\begin{array}{c}0.001 \\
{[0.010]}\end{array}$ & & \\
\hline log.netincome & $\begin{array}{c}-0.050 \\
{[0.030]}\end{array}$ & $\begin{array}{c}-0.037 * \\
{[0.019]}\end{array}$ & $\begin{array}{c}-0.115^{*} \\
{[0.062]}\end{array}$ & $\begin{array}{c}-0.129 * * \\
{[0.055]}\end{array}$ & $\begin{array}{c}-0.053 \\
{[0.039]}\end{array}$ & & $\begin{array}{c}0.0226 \\
{[0.017]}\end{array}$ \\
\hline L.log.netincome & & & & & $\begin{array}{c}-0.007 \\
{[0.025]}\end{array}$ & & \\
\hline Vol & $\begin{array}{c}-0.876 \\
{[1.821]}\end{array}$ & $\begin{array}{c}-1.608 * \\
{[0.828]}\end{array}$ & & $\begin{array}{c}5.299 \\
{[3.271]}\end{array}$ & $\begin{array}{c}-4.724 * * * \\
{[1.211]}\end{array}$ & & \\
\hline L.vol & & & & & $\begin{array}{c}4.103 * * * \\
{[0.632]}\end{array}$ & & \\
\hline Marketcapitalisation & & & & & & & $\begin{array}{c}0.0867 * * \\
{[0.040]}\end{array}$ \\
\hline Intrate & & $\begin{array}{c}0.002 \\
{[0.006]}\end{array}$ & $\begin{array}{c}0.00513 \\
{[0.017]}\end{array}$ & $\begin{array}{c}0.034 \\
{[0.020]}\end{array}$ & $\begin{array}{c}0.024 * * \\
{[0.011]}\end{array}$ & $\begin{array}{c}-0.0103 \\
{[0.0169]}\end{array}$ & $\begin{array}{c}-0.00531 \\
{[0.008]}\end{array}$ \\
\hline L.intrate & & & & & $\begin{array}{c}-0.029 * * \\
{[0.012]}\end{array}$ & & \\
\hline Region & & & $\begin{array}{c}0.0308 \\
{[0.177]}\end{array}$ & $\begin{array}{l}0.436^{*} \\
{[0.240]}\end{array}$ & & & \\
\hline Constant & $\begin{array}{l}0.735^{*} \\
{[0.418]}\end{array}$ & $\begin{array}{c}0.315 \\
{[0.192]}\end{array}$ & $\begin{array}{c}0.754 * * \\
{[0.309]}\end{array}$ & $\begin{array}{c}0.032 \\
{[0.405]}\end{array}$ & $\begin{array}{c}0.633 * * * \\
{[0.241]}\end{array}$ & $\begin{array}{c}0.78 * * * \\
{[0.230]}\end{array}$ & $\begin{array}{c}-0.262 \\
{[0.194]}\end{array}$ \\
\hline Observations & 3361 & 3907 & 7777 & 6142 & 8540 & 5834 & 931 \\
\hline Number of $t$ & 651 & 661 & 1749 & 1566 & 1532 & 1726 & 219 \\
\hline Hansen statistic & 41.32 & 79.40 & 18.49 & 6.316 & 123.1 & 23.82 & 91.80 \\
\hline $\begin{array}{l}\text { p-value of Hansen statistic } \\
\text { Arellano-Bond test for }\end{array}$ & 0.288 & 0.215 & 0.238 & 0.851 & 0,123 & 0.161 & 0.238 \\
\hline $\mathrm{AR}(2)$ & 0.00314 & -0.502 & 1.407 & -0.280 & 0.634 & -0.123 & 0.776 \\
\hline p-value AR2 & 0.997 & 0.616 & 0.160 & 0.780 & 0.526 & 0.902 & 0.438 \\
\hline
\end{tabular}

Standard errors in brackets

* significant at $10 \%$;* significant at $5 \%$; *** significant at $1 \%$

The table shows different signs for different lags, we take the sum of coefficients to determine the overall sign. 
After checking the validity of our estimations, we can now state our results. First, we observe that risk taking in period $t$ is influenced by risk taking in period $t-1, t-2$, but not always in $t-3$. Risk taking in period $t$ is affected by overall risk taking in the three previous years (in table 2 the sum of the coefficients L.risk, L2.risk, L3.risk is positive and significant). The closer we get to period $t$, the higher the influence of the former period risk taking.

Second, as explained above, we control the analysis for the following variables: volatility, housing prices, economic growth, industrialized vs. developing countries, non-performing loans, net income of banks, return on average equity, return on average asset, and prudential ratio.

On the one hand, our results underline the influence of the economic and financial context on banks' risk taking. We observe that the lower the volatility in period $t$, the higher is risk taking in period $t$ (and $t, t-1)(\mathrm{vol})$. The rationale for such result is that when volatility is low, banks are incited to take on more risks which increases the share of short term assets (dependent variable denominator). Hence our results are in line with the theoretical analysis of Brunnermeier (2001) and Rajan (2005). The procyclical behavior of volatilities is a concrete manifestation of the influence on risk perceptions. By contrast, the stronger growth, the higher is risk taking $(g d p)$ : as output grows there are more yield opportunities and economic agents search for new investment opportunities. Controlling for housing prices, we also observe a positive relationship: as housing prices rise, risk taking increases (prices). This demonstrates that economic agents and financial institutions try to benefit from a bubble, as suggested by the rational bubbles phenomenon of Blanchard and Watson (1983). According to them, rational bubbles may yield multiple equilibria that can explain deviations from the fundamentals and the existence of self-sustaining dynamics. Comparing industrialized to developing countries, we observe that risk taking is higher in the former (region). One interpretation might be that emerging countries have drawn the lessons from previous crises, especially owing to prudential policies implemented in these countries, such as controlling entrance of short term capital inflows and managing the illiquidity risk in the banking sector. Another prominent view (Bernanke (2005)) is that an excess of saving over investment in emerging market countries, eased financial conditions and exerted significant downward pressure on world interest rates. In so doing, this flow of saving helped to fuel a credit boom and risk-taking in major advanced economies, particularly in the United States. Over the long run $(t, t-1)$, low interest rates generate high risk taking. The idea is to consider that monetary policy could have contributed to the crisis. Low interest rates affect valuations, incomes and cash flows, which in turn can influence how banks measure risk (Adrian and Shin, 2009a, b, Borio and Zhu, 2008). Lower interest rates, for instance, boost asset and collateral values as well as incomes and profits, which in turn can reduce risk perceptions and/or increase risk tolerance. In this respect our results converge toward those of Altunbas et al. (2010) who empirically analyze the relationship between monetary policy and risk-taking by banks using a sample of 1,100 European and US banks. They find evidence that relative changes in banks' risk-attitude (i.e. comparing risky versus less risky 
banks as perceived by the market) are linked to monetary policy even in a period of subdued risk perception. More precisely, unusually low interest rates over an extended period of time contributed to an increase in bank' risk.

On the other hand, the specific bank variables play a role in the risk taking dynamics. At the banks' scale, the higher net income, the lower is risk taking (netincome). This result underlines the fact that smaller banks are induced to take more risk. This phenomenon can be explained by the fact that those banks hold less liabilities compared to bigger ones, and so the share of short term assets relatively to long term liabilities is smaller. Indeed, smaller banks generally have less liquid balance sheets (lower ratios of securities to assets) (Kashyap et al. (2000)). The lower the return (roae for return on average equity and), the higher is risk taking, indicating that banks search for yield. Low returns on investments, such as government (risk-free) securities, may increase incentives for banks to take on more risk to meet a nominal return target (Young et al., 2010). The higher market capitalization (marketkp), the higher is risk taking. The more banks' capitalization is concentrated, the more banks take risks. Indeed, the less a bank has shareholders, the more risks it takes; such a behavior can be associated with a specific management mode of slightly capitalized banks. According to Laeven and Levine (2009), bank risk taking varies positively with the comparative power of shareholders within the corporate governance structure of banks. Finally, the higher prudential ratio, the lower is risk taking (totcap), which suggests that macro-policy tends to reduce risk on a global basis. Finally, the lower the amount of non-performing loans, the higher should be risk taking, indicating that banks' vulnerability tends to reduce maturity mismatch $(n p l)$. The mortgage expansion is accompanied by an increase in NPLs masked by the house prices growth (Claessens et al. (2010)). This variable is only significant for the GMM system. We cannot therefore make a definitive conclusion.

4.2. Testing the disaster myopia hypothesis: the particular case of 2007 and previous years

To test the disaster myopia hypothesis, we resort to two types of estimations: cross-section and crosssection with country dummies. We consider two periods of time: starting from 2009 backward and starting from 2007 backward. We observe that results converge for any of the two methods (Tables 3 and 4). 
Table 3. Dynamics of risk taking during the recent crisis (OLS)

\begin{tabular}{|l|ccccccccc|}
\hline Variables & risk2009 & risk2009 & risk2009 & risk2009 & risk2009 & risk2007 & risk2007 & risk2007 & risk2007 \\
\hline risk2008 & $0.757^{* * *}$ & $0.757^{* * *}$ & $0.770^{* * *}$ & $0.766^{* * *}$ & $0.766^{* * *}$ & & & & \\
& {$[51.11]$} & {$[51.08]$} & {$[51.72]$} & {$[51.24]$} & {$[50.75]$} & & & & \\
risk2007 & -0.013 & -0.002 & -0.029 & -0.020 & -0.021 & & & & \\
& {$[-0.802]$} & {$[-0.0695]$} & {$[-1.329]$} & {$[-0.891]$} & {$[-0.919]$} & & & & \\
risk2006 & & -0.013 & $-0.120^{* * *}$ & $-0.132^{* * *}$ & $-0.132 * * *$ & $0.857 * * *$ & $0.626^{* * *}$ & $0.643 * * *$ & $0.643 * * *$ \\
& & {$[-0.795]$} & {$[-4.662]$} & {$[-5.070]$} & {$[-5.051]$} & {$[63.10]$} & {$[24.46]$} & {$[24.97]$} & {$[24.96]$} \\
risk2005 & & & $0.144^{* * *}$ & $0.077 * *$ & $0.078^{* *}$ & & $0.283 * * *$ & $0.407 * * *$ & $0.408^{* * *}$ \\
& & & {$[5.257]$} & {$[2.188]$} & {$[2.200]$} & & {$[9.660]$} & {$[10.87]$} & {$[10.86]$} \\
risk2004 & & & & $0.082 * * *$ & $0.091 * *$ & & & $-0.16^{* * *}$ & $-0.14 * * *$ \\
& & & & {$[2.978]$} & {$[2.415]$} & & & {$[-5.316]$} & {$[-3.550]$} \\
risk2003 & & & & & -0.010 & & & -0.015 \\
& & & & & {$[-0.340]$} & & & {$[-0.496]$} \\
Constant & $0.329 * * *$ & $0.331 * * *$ & $0.304 * * *$ & $0.292^{* * *}$ & $0.293 * * *$ & $0.257 * * *$ & $0.193 * * *$ & $0.214^{* * *}$ & $0.215 * * *$ \\
& {$[13.33]$} & {$[13.31]$} & {$[11.92]$} & {$[11.32]$} & {$[11.31]$} & {$[9.57]$} & {$[7.001]$} & {$[7.730]$} & {$[7.747]$} \\
\hline Obs. & 3027 & 3023 & 2999 & 2986 & 2981 & 872 & 3003 & 2990 & 2985 \\
R-squared & 0.761 & 0.761 & 0.764 & 0.764 & 0.764 & 0.741 & 0.748 & 0.749 & 0.749 \\
\hline
\end{tabular}

$t$-statistics in brackets

* significant at 10\%; ** significant at 5\%; *** significant at $1 \%$

Table 4. Dynamics of risk taking during the recent crisis (Country dummies)

\begin{tabular}{|l|ccccccccc|}
\hline Variables & risk2009 & risk2009 & risk2009 & risk2009 & risk2009 & risk2007 & risk2007 & risk2007 & risk2007 \\
\cline { 2 - 10 } risk2008 & $0.759^{* * *}$ & $0.759^{* * *}$ & $0.771^{* * *}$ & $0.767^{* * *}$ & $0.767^{* * *}$ & & & & \\
& {$[50.05]$} & {$[50.00]$} & {$[50.61]$} & {$[50.14]$} & {$[49.59]$} & & & & \\
risk2007 & -0.026 & -0.024 & $-0.050^{* *}$ & $-0.041^{*}$ & $-0.041^{*}$ & & & & \\
& {$[-1.558]$} & {$[-1.050]$} & {$[-2.184]$} & {$[-1.756]$} & {$[-1.760]$} & & & & \\
risk2006 & & -0.002 & $-0.104^{* * *}$ & $-0.116^{* * *}$ & $-0.116^{* * *}$ & $0.854^{* * *}$ & $0.641^{* * *}$ & $0.656^{* * *}$ & $0.657^{* * *}$ \\
& & {$[-0.147]$} & {$[-3.932]$} & {$[-4.333]$} & {$[-4.319]$} & {$[92.55]$} & {$[24.77]$} & {$[25.26]$} & {$[25.25]$} \\
risk2005 & & & $0.135^{* * *}$ & $0.069^{*}$ & $0.069^{*}$ & & $0.260^{* * *}$ & $0.383^{* * *}$ & $0.385^{* * *}$ \\
& & & {$[4.859]$} & {$[1.911]$} & {$[1.910]$} & & {$[8.789]$} & {$[10.08]$} & {$[10.09]$} \\
risk2004 & & & & $0.082^{* * *}$ & $0.085^{* *}$ & & & $-0.155^{* * *}$ & $-0.138^{* * *}$ \\
& & & & {$[2.896]$} & {$[2.231]$} & & & {$[-5.162]$} & {$[-3.375]$} \\
risk2003 & & & & & -0.004 & & & -0.019 \\
& & & & & {$[-0.144]$} & & & {$[-0.613]$} \\
Constant & -0.079 & -0.078 & -0.133 & -0.156 & -0.156 & 0.221 & 0.217 & 0.293 & 0.299 \\
& {$[-0.0948]$} & {$[-0.0938]$} & {$[-0.161]$} & {$[-0.188]$} & {$[-0.188]$} & {$[0.246]$} & {$[0.243]$} & {$[0.330]$} & {$[0.336]$} \\
\hline Obs. & 3015 & 3011 & 2987 & 2974 & 2969 & 3016 & 2991 & 2978 & 2973 \\
R-squared & 0.770 & 0.770 & 0.773 & 0.773 & 0.773 & 0.758 & 0.762 & 0.764 & 0.764 \\
\hline
\end{tabular}

$t$-statistics in brackets

* significant at 10\%; ** significant at 5\%; *** significant at $1 \%$

For the period from 2002 to 2009 , we observe that banks' risk taking in 2009 is positively influenced by their risk taking in 2008 and negatively by their risk taking in 2006 (coefficients are stable from regression to the next). There is therefore a break in risk taking due to the negative shock that 
occurred in 2007. The lower risk taking in 2008 induced also a lower risk taking in 2009. By comparison, for the period from 2002 to 2007, we observe that the influence of risk taking is increasing over time starting from 2004.

We can thus conclude that the episode of the 2007 crisis shows evidence of banks' myopia disaster. This result is in accordance with the aforementioned GMM results.

\section{Discussion about policy implications}

As regulators and institutions are more immune to disaster myopia ${ }^{7}$, they must design stress scenarios integrating extreme events and impose them to financial institutions. Regulators must also consider more deeply models used by financial institutions, in particular the historical statistics series used to estimate risks. All this can be done via prudential supervision accompanied by measures of transparency.

\subsection{Prudential supervision}

Preventing the development of financial conditions that are vulnerable to crisis is the role of prudential supervision. More precisely, prudential supervision should help identify vulnerable banks before they become weak banks and especially banks that are becoming heavily exposed to a major shock. The recommendations of the Basel Committee on Banking Supervision go in this direction.

According to the Basel Committee on Banking Supervision (hereafter BCBS) (2009a), stress tests should be performed for different risk types including market, credit, operational and liquidity risk. According to Haldane (2009), the evaluation of the degree of risk - the value at risk for the private sector and the stress-tests for the public one- was based on data and assumptions relative to the Golden Era. This period is characterized by a strikingly low volatility from an historical perspective inducing a low degree of risk that conduced to disaster myopia. Using British historical data -back in some cases to the $17^{\text {th }}$ century- Haldane shows that the low macroeconomic and financial volatility level during this Golden Era has been without historical equivalent. As a result, this lack of historical perspective to assess the risk level has led to disaster myopia. According to Haldane (2009), 'the stress-tests required by the authorities over the past few years were too heavily influenced by behaviour during the Golden Decade'. Therefore, as required by the BCBS, a bank should enhance its stress testing practices by considering important interrelations between various factors, including: (i) price shocks for specific asset categories; (ii) the drying-up of corresponding asset liquidity; (iii) the

\footnotetext{
${ }^{7}$ Identifying whether there is or not a difference between the private sector and the official sector in terms of disaster myopia is another issue that is not dealt with in this paper. Haldane (2009) stresses that both the private and the public sectors suffer from a disaster myopia behavior.
} 
possibility of significant losses damaging the bank's financial strength; (iv) growth of liquidity needs as a consequence of liquidity commitments; (v) taking on board affected assets; and (vi) diminished access to secured or unsecured funding markets.

The Basel Committee on Banking Supervision (2009b and 2009c) also made a few propositions aiming at limiting banks' risk by establishing some ratios. Both the Liquidity Coverage Ratio and the Net Stable Funding Ratio proposed by the Basel Committee on Banking Supervision intend to limit risk. The liquidity coverage ratio is also useful in this respect, as it identifies the amount of unencumbered, high quality liquid assets an institution holds that can be used to offset the net cash outflows it would encounter under an acute short-term stress scenario specified by supervisors. The net stable funding ratio measures the amount of longer-term, stable sources of funding employed by an institution relative to the liquidity profiles of the assets funded and the potential for contingent calls on funding liquidity arising from off-balance sheet commitments and obligations. The standard requires a minimum amount of funding that is expected to be stable over a one year time horizon based on liquidity risk factors assigned to assets and off-balance sheet liquidity exposures. This ratio is intended to promote longer-term structural funding of banks' balance sheets, off-balance sheet exposures and capital markets activities. To deal with banks' liquidity risk, the Committee also proposes that banks should frequently conduct a contractual maturity mismatch assessment.

\subsection{Announcements and transparency}

In parallel, policy-makers may attempt to avert a financial crisis by announcing policies that will reduce the likelihood of a disaster or mitigate its impact. For example, the development of indicators of increasing vulnerability to financial crises could provide a useful counter to disaster myopia. Macroprudential indicators may help deter disaster myopia.

Factors that encourage disaster myopia should also be dealt with. Opaque accounting practices, which obscure the magnitude of the exposure of the consolidated financial institution or mask deterioration in the market value of exposures, are a fundamental source of vulnerability. Exante public disclosure of exposures to credit risk may exercise some constraining influence.

\section{Conclusion}

The contribution of this paper is twofold. First, it shows that the 2007 financial crisis exhibits disaster myopia in the banking sector. Disaster myopia suggests that competitive, incentive-based and psychological mechanisms in the presence of uncertainty lead financial institutions to underestimate the risk of financial instability. Second, this paper identifies macro and specific determinant variables in banks' risk taking since the beginning of the years 2000. The recognition of conditions that promote 
disaster myopia is the starting point. In terms of economic policy, there is a need for advances in modelling credit risk and greater discipline of the pricing of credit risk. Identifying and limiting the impact of the banking sector's disaster myopia is helpful as it may limit the consequences for the system as a whole. Indeed, because of the particular and systemic role of banks in the financing of the economy, the impact of banking sector myopia on the economy may grow so large that they can jeopardize the financial system.

An open question for future research is whether disaster myopia is more prominent during the recent financial crisis than during previous financial distresses. More precisely, is the current financial crisis special in this respect? We expect the disaster myopia problem to be more acute today because of the complexity and opacity of new financial products.

\section{References}

Adrian T. and Shin H.S. (2009a), "Money, Liquidity, and Monetary Policy", American Economic Review, Vol. 99, No. 2, pp. 600-605.

Adrian T. and Shin H.S. (2009b), "Financial Intermediation and Monetary Economics", Federal Reserve Bank of New York Staff Reports, No. 398.

Allegret J.P. and Cornand C. (2011), "Financial Crisis and Information", mimeo.

Andersen T.G., Bollerslev, T., Diebold F.X. and Labys P. (2003), "Modeling and Forecasting Realized Volatility", Econometrica, Vol. 71, pp. 579-625.

Andersen T.G., Bollerslev, T. and Diebold F.X. (2009), "Parametric and Nonparametric Volatility Measurement" in L.P. Hansen and Y. Aït-Sahalia (eds.), Handbook of Financial Econometrics, Amsterdam: North-Holland, 67-138.

Altunbas Y., Gambacorta L. and Marques-Ibanez D. (2010), "Does monetary policy affect bank risktaking?", BIS Working Papers No 298. http://www.bis.org/publ/work298.pdf

Arellano M. and Bond S.R. (1991), "Some Tests of Specification for Panel Data: Monte Carlo Evidence and an Application to Employment Equations", Review of Economic Studies, Vol. 58, pp. 277-297.

Basel Committee on Banking Supervision (2009a), Consultative Document - Principles for sound stress testing practices and supervision, Bank for International Settlements, January, Issued for comment by 13 March 2009. http://www.bis.org/publ/bcbs147.pdf

Basel Committee on Banking Supervision (2009b), Consultative Document - Strengthening the resilience of the banking sector, Bank for International Settlements, December, Issued for comment by 16 April 2010. http://www.bis.org/publ/bcbs164.pdf

Basel Committee on Banking Supervision (2009c), Consultative Document - International framework for liquidity risk measurement, standards and monitoring, Bank for International Settlements, December, Issued for comment by 16 April 2010.http://www.bis.org/publ/bcbs165.pdf

Barrell R., Davis E.P., Fic T., and Karim D. (2010), "Is there a link from bank size to risk taking?", NIESR Discussion Paper No. 367. http://www.niesr.ac.uk/pdf/dp367.pdf

Bernanke B. (2005), "The global saving glut and the U.S. current account deficit", speech at the Sandridge Lecture, Richmond, March 10. 
Bird G. and Rajan R. S. (2001), "Banks, Maturity Mismatches and Liquidity Crises: A Simple Model". http://www.freewebs.com/rrajan01/0132.pdf

Blanchard O. J. and Watson M. W. (1983), "Bubbles, Rational Expectations and Financial Markets", NBER Working Paper Series, Vol. w0945, June.

Blundell R. and Bond S.R. (1998), "Initial Conditions and Moment Restrictions in Dynamic Panel Data Models", Journal of Econometrics, Vol. 87(1), pp. 115-143.

Borio C. and Zhu H. (2008), "Capital regulation, risk-taking and monetary policy: a missing link in the transmission mechanism?", Bank for International Settlements Working Papers No 268, December. http://www.bis.org/publ/work268.htm

Brunnermeier M.K. (2001), Asset Pricing under Asymmetric Information-Bubbles, Crashes, Technical Analysis and Herding, Oxford, Oxford University Press.

Bullard J., Neely C. J., and Wheelock D.C. (2009), "Systemic Risk and the Financial Crisis: A Primer", Federal Reserve Bank of St. Louis Review, September/October, 91(5, Part 1), pp. 403-417.

Chan, W. H., Jha R. and Kalimipalli M. (2009), "The Economic Value of Using Realized Volatility in Forecasting Future Implied Volatility", Journal of Financial Research, Vol. 32(3), pp. 231-259.

Calomiris C. W. (1990). "Is Deposit Insurance Necessary? A Historical Perspective," Journal of Economic History, Vol. 50, pp. 283-329.

Claessens S., Kose M. A. and Terrones M. E. (2010), "The global financial crisis: How similar? How different? How costly?", Journal of Asian Economics, Vol. 21, pp. 247-264.

Diamond D. W. and Rajan R. G (2009), "The credit crisis: conjectures about causes and remedies", American Economic Review, Vol. 99, pp. 606-610.

Esty B. C. (1998), "The Impact of Contingent Liability on Commercial Bank Risk Taking", Journal of Financial Economics, Vol. 47(2), pp. 189-218.

Farhi E. and Tirole J. (2009), "Collective moral hazard, maturity mismatch and systemic bailouts", Working Paper: http://www.economics.harvard.edu/faculty/farhi/files/collectivemh.pdf.

Garlappi L., Uppal R. and Wang T. (2007), "Portfolio Selection with Parameter and Model Uncertainty: A Multi-Prior Approach", Review of Financial Studies, Vol. 20, No 1, pp. 41-81.

Grossman R. S. (2001), "Double Liability and Bank Risk Taking", Journal of Money, Credit and Banking, Vol. 33(2), pp. 143-59.

Grossman R. S. (2007), "Fear and Greed: The Evolution of Double Liability in American Banking, 1865-1930", Explorations in Economic History, Vol. 44(1), pp. 59-80.

Grossman R. S. and Imai M. (2010), "Contingent Capital and Bank Risk-Taking: Evidence from British Equity Markets before World War I", Paper prepared for the Economic History Association Meetings, Evanston, IL, September 24-26.

Guttentag J. and Herring R. (1984), "Commercial Bank Lending to Less Developed Countries: From Overlending to Underlending to Structural Reform", Brookings Discussion Papers in International Economics 16, Washington D.C.: Brookings Institution, June.

Guttentag J.M. and Herring R.J. (1986), "Disaster Myopia in International Banking", Essays in International Finance, $\mathrm{n}^{\circ} 164$.

Hakenes H. and Schnabel I. (2005), "Bank Size and Risk-Taking under Basel II", MPI Collective Goods Preprint No. 2005/6, March 22.

Haldane A.G. (2009), "Why Banks Failed the Stress Test", speech given at the Marcus-Evans Conference on Stress-Testing, 9-10 February 2009.

Herring R.J. (1998), "Banking Disasters: Causes and Preventative Measures, Lessons Derived from the U.S. Experience", in Preventing Bank Crises - Lessons from Recent Global Bank Failures, ed. By 
Caprio G. Jr., Hunter W.C., Kaufman G.G., Leipziger D.M., Proceedings of a conference cosponsored by the Federal Reserve Bank of Chicago and the Economic Development Institute of the World Bank, The World Bank, Washington D.C., September, pp. 209-236.

Herring R.J. (1999), "Credit risk and financial instability", Oxford Review of Economic Policy, Vol. $15, \mathrm{n}^{\circ} 3$.

Herring R.J. (2008), "Comment on Franke \& Krahnen: The Future of Securitization", BrookingsTokyo Club-Wharton Conference, October 15.

Herring R.J. and Wachter S. (2002), "Bubbles in Real Estate Markets", Zell/Lurie Real Estate Center Working Paper \#402, March.

Kahneman D., Slovic P. and Tversky A. (1982), Judgment under uncertainty: Heuristics and biases. New York: Cambridge University Press.

Kashyap A. K. and Stein J. (2000), "What Do a Million Observations on Banks Say About the Transmission of Monetary Policy?", American Economic Review, Vol. 90(3), pp. 407-428.

Kay J. (2009), Narrow Banking: The Reform of Banking Regulation, Centre for the Study of Financial Innovation. http://www.johnkay.com/2009/09/15/narrow-banking

Laeven L. and Levine R. (2009), "Bank governance, regulation and risk taking", Journal of Financial Economics, Vol. 93(2), pp. 259-275,

Minsky H. P. (1982), "The financial instability hypothesis, capitalist processes and the behaviour economy", in Kindelberger C.P. and J.P. Laffargue (eds.), Financial Crises, Theory and Policy, Cambridge, Cambridge University Press.

Rajan R.G. (2005), "Has Financial Development Made the World Riskier?", National Bureau of Economic Research Working Paper Series, No. 11728.

Saunders A., Strock E. and Travlos N.G. (1990), "Ownership Structure, Deregulation, and Bank Risk Taking", Journal of Finance, Vol. 45(2), pp. 643-654.

Young A. T., Wiseman T., Hogan T. L. (2010), "Changing Perceptions of Maturity Mismatch in the US Banking System: Evidence from Equity Markets", mimeo, April.

\section{Appendix}

\section{A - Summary}

Table 5. Descriptive statistics

\begin{tabular}{|c|c|c|c|c|c|}
\hline Variable & Obs & Mean & Std.Dev. & Min & Max \\
\hline intrate & 52152 & 2.707955 & 2.968118 & .0008508 & 86.0976 \\
\hline$g d p$ & 57336 & 1.838918 & 2.62559 & -17.955 & 27.3205 \\
\hline Risk & 24311 & -.160716 & .611732 & -5.274448 & 1.926958 \\
\hline Vol & 50787 & .0669429 & .7020496 & .0032289 & 20.99577 \\
\hline prices & 42798 & 2.570203 & 4.841805 & -11.21511 & 19.26538 \\
\hline Totkt & 10850 & 20.93146 & 44.11118 & .01 & 982.6001 \\
\hline Roae & 22111 & 12.10005 & 21.22037 & .004 & 850.2368 \\
\hline marketkp & 3740 & 2.368776 & 21.30123 & .001 & 783.3738 \\
\hline netincome & 22124 & 3.947497 & .9159321 & .8086932 & 7.394924 \\
\hline$n p l$ & 7247 & 4.645931 & 10.32534 & 0 & 228.7 \\
\hline
\end{tabular}




\section{B - Different estimations of the same model (OLS, Within-group and GMM difference)}

Table 6. GMM difference results

\begin{tabular}{|c|c|c|c|c|c|c|c|}
\hline & GMM Diff & GMM Diff & GMM Diff & GMM Diff & GMM Diff & GMM Diff & GMM Diff \\
\hline L.risk & $\begin{array}{c}0.625 * * * \\
{[0.082]}\end{array}$ & $\begin{array}{c}0.591 * * * \\
{[0.064]}\end{array}$ & $\begin{array}{c}0.580 * * * \\
{[0.0685]}\end{array}$ & $\begin{array}{c}0.487 * * * \\
{[0.074]}\end{array}$ & $\begin{array}{c}0.567 * * * \\
{[0.062]}\end{array}$ & $\begin{array}{c}0.591 * * * \\
{[0.110]}\end{array}$ & $\begin{array}{c}0.257 * * * \\
{[0.024]}\end{array}$ \\
\hline L2.risk & & & & $\begin{array}{l}0.141^{* *} \\
{[0.056]}\end{array}$ & $\begin{array}{c}0.039 \\
{[0.033]}\end{array}$ & $\begin{array}{c}0.106^{*} \\
{[0.0570]}\end{array}$ & $\begin{array}{c}-0.00726 \\
{[0.016]}\end{array}$ \\
\hline L3.risk & & & & & & $\begin{array}{c}-0.0409 \\
{[0.0465]}\end{array}$ & $\begin{array}{c}0.0689 * * * \\
{[0.015]}\end{array}$ \\
\hline totkt & & & $\begin{array}{c}0.00612 \\
{[0.00542]}\end{array}$ & $\begin{array}{l}-0.000 \\
{[0.004]}\end{array}$ & & $\begin{array}{c}0.0140 \\
{[0.0119]}\end{array}$ & \\
\hline roae & & & & & & $\begin{array}{c}-0.0340 * * * \\
{[0.0100]}\end{array}$ & \\
\hline npl & $\begin{array}{c}-0.018 * * * \\
{[0.005]}\end{array}$ & $\begin{array}{c}-0.009 * * * \\
{[0.003]}\end{array}$ & & & & & $\begin{array}{c}-0.00120 \\
{[0.002]}\end{array}$ \\
\hline prices & $\begin{array}{c}0.011^{*} \\
{[0.006]}\end{array}$ & & & & & & \\
\hline gdp & & $\begin{array}{l}-0.014 \\
{[0.020]}\end{array}$ & $\begin{array}{c}-0.00788 \\
{[0.0364]}\end{array}$ & $\begin{array}{c}0.018 \\
{[0.055]}\end{array}$ & $\begin{array}{c}0.004 \\
{[0.012]}\end{array}$ & $\begin{array}{c}-0.0187 \\
{[0.0214]}\end{array}$ & \\
\hline L.gdp & & & & & $\begin{array}{c}0.031^{* * *} \\
{[0.010]}\end{array}$ & & \\
\hline log.netincome & $\begin{array}{l}-0.208^{*} \\
{[0.118]}\end{array}$ & $\begin{array}{c}0.003 \\
{[0.078]}\end{array}$ & $\begin{array}{c}-0.629 * * * \\
{[0.204]}\end{array}$ & $\begin{array}{c}-0.475 * * \\
{[0.231]}\end{array}$ & $\begin{array}{c}-0.317 * * * \\
{[0.061]}\end{array}$ & & $\begin{array}{c}-0.0733 * * * \\
{[0.025]}\end{array}$ \\
\hline L.log.netincome & & & & & $\begin{array}{c}0.062 \\
{[0.050]}\end{array}$ & & \\
\hline 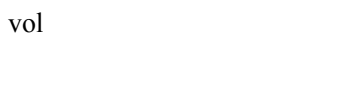 & $\begin{array}{c}-2.603 \\
{[1.883]}\end{array}$ & $\begin{array}{c}-0.534 \\
{[0.994]}\end{array}$ & & $\begin{array}{c}5.194 \\
{[1.416]}\end{array}$ & $\begin{array}{c}-3.666^{* * *} \\
{[3.667]}\end{array}$ & & \\
\hline L.vol & & & & & $\begin{array}{c}1.059 \\
{[0.750]}\end{array}$ & & \\
\hline marketcapitalisation & & & & & & & $\begin{array}{c}0.0533 * * * \\
{[0.019]}\end{array}$ \\
\hline intrate & & $\begin{array}{l}-0.004 \\
{[0.008]}\end{array}$ & $\begin{array}{c}-0.00804 \\
{[0.0206]}\end{array}$ & $\begin{array}{c}0.040 \\
{[0.892]}\end{array}$ & $\begin{array}{c}0.031 * * * \\
{[0.044]}\end{array}$ & $\begin{array}{c}-0.0218 \\
{[0.0225]}\end{array}$ & $\begin{array}{c}-0.00521 \\
{[0.004]}\end{array}$ \\
\hline Observations & 2663 & 3166 & 5799 & 4448 & 6985 & 3995 & 704 \\
\hline Number of $t$ & 625 & 638 & 1506 & 1349 & 1519 & 1470 & 217 \\
\hline Hansen statistic & 16.66 & 134.7 & 5.660 & 3.519 & 79.55 & 6.004 & 61.18 \\
\hline p-value of Hansen statistic & 0.408 & 0.144 & 0.843 & 0.621 & 0.000199 & 0.946 & 0.206 \\
\hline Arellano-Bond test for $\mathrm{AR}(2)$ & 0.199 & 0.695 & 1.416 & -0.483 & 0.440 & 0.00424 & 0.709 \\
\hline $\mathrm{p}$-value AR2 & 0.842 & 0.974 & 0.157 & 0.629 & 0.660 & 0.997 & 0.478 \\
\hline
\end{tabular}

Standard errors in brackets

* significant at $10 \% ; * *$ significant at $5 \% ; * * *$ significant at $1 \%$ 
Tables 7. OLS and panel Fixed Effects results

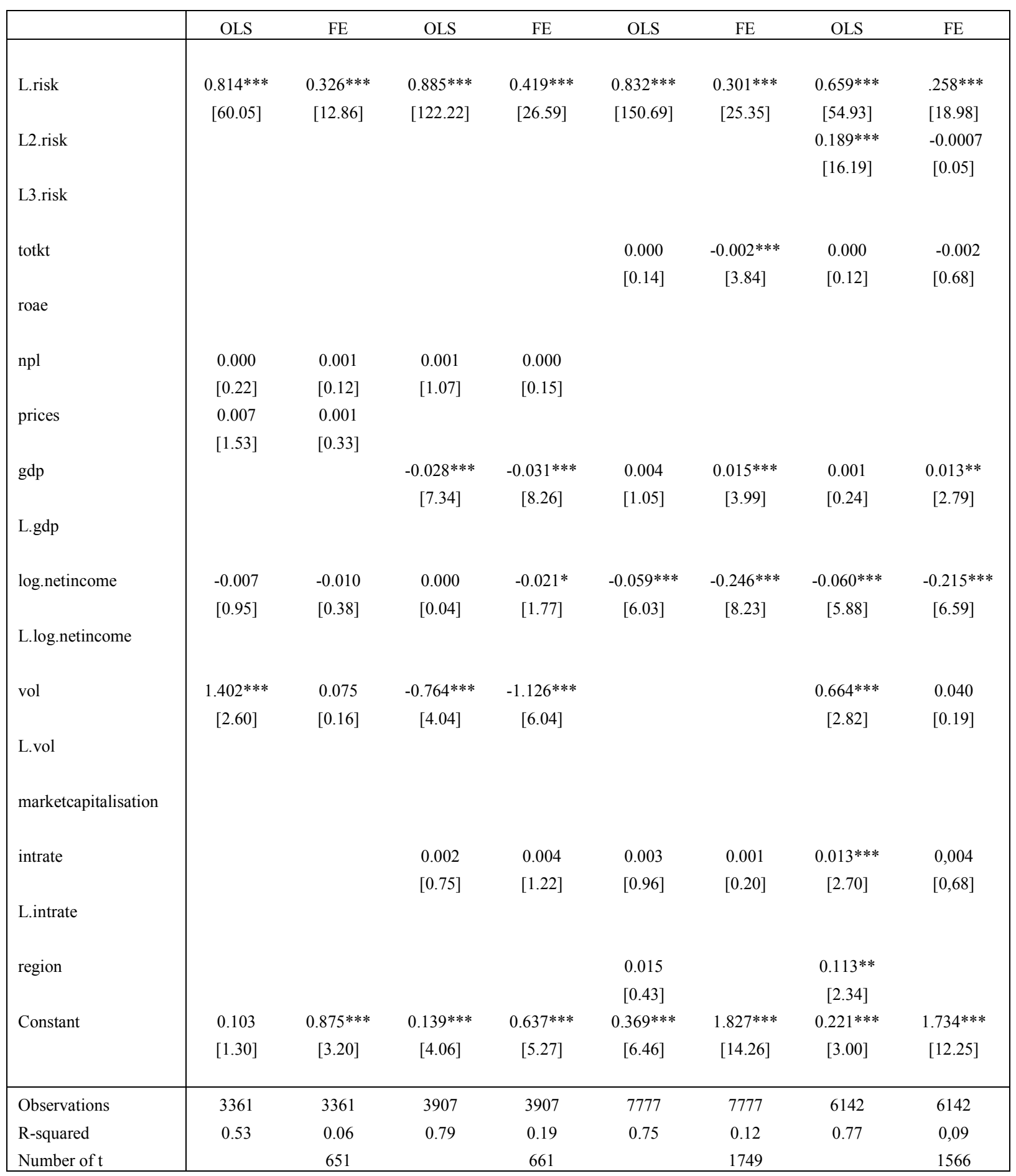

Absolute value of $\mathrm{t}$ statistics in brackets

* significant at $10 \% ; * *$ significant at $5 \% ; * * *$ significant at $1 \%$ 


\begin{tabular}{|c|c|c|c|c|c|c|}
\hline & OLS & $\mathrm{FE}$ & OLS & $\mathrm{FE}$ & OLS & $\mathrm{FE}$ \\
\hline L.risk & $\begin{array}{c}0.895 * * * \\
{[77.78]}\end{array}$ & $\begin{array}{c}0.557 * * * \\
{[42.89]}\end{array}$ & $\begin{array}{c}0.664 * * * \\
{[49.69]}\end{array}$ & $\begin{array}{c}0.185^{* * *} \\
{[11.73]}\end{array}$ & $\begin{array}{c}0.729 * * * \\
{[25.39]}\end{array}$ & $\begin{array}{c}0.263 * * * \\
{[8.47]}\end{array}$ \\
\hline L2.risk & $\begin{array}{c}0.052 * * * \\
{[4.36]}\end{array}$ & $\begin{array}{c}-0.124 * * * \\
{[7.99]}\end{array}$ & $\begin{array}{c}0.137 * * * \\
{[8.74]}\end{array}$ & $\begin{array}{c}-0.029 * \\
{[1.83]}\end{array}$ & $\begin{array}{l}-0.055 \\
{[1.64]}\end{array}$ & $\begin{array}{l}-0.038 \\
{[1.31]}\end{array}$ \\
\hline L3.risk & & & $0.047 * * *$ & $-0.078^{* * *}$ & $\begin{array}{c}0.106^{* * * *} \\
{[4.66]}\end{array}$ & $\begin{array}{c}0.044 * \\
{[1.94]}\end{array}$ \\
\hline totkt & & & $\begin{array}{l}0.000 \\
{[0.25]}\end{array}$ & $\begin{array}{l}-0.001 \\
{[1.36]}\end{array}$ & & \\
\hline roae & & & $\begin{array}{c}-0.003 * * * \\
{[3.57]}\end{array}$ & $\begin{array}{l}-0.001 \\
{[0.76]}\end{array}$ & & \\
\hline npl & & & & & $\begin{array}{l}0.001 \\
{[0.39]}\end{array}$ & $\begin{array}{l}0.000 \\
{[0.01]}\end{array}$ \\
\hline prices & & & & & & \\
\hline gdp & $\begin{array}{c}0.009 * \\
{[1.75]}\end{array}$ & $\begin{array}{c}0.014 * \\
{[1.94]}\end{array}$ & $\begin{array}{c}0.002 \\
{[0.37]}\end{array}$ & $\begin{array}{c}0.020 * * * \\
{[4.04]}\end{array}$ & & \\
\hline L.gdp & $\begin{array}{l}0.010 \\
{[1.62]}\end{array}$ & $\begin{array}{c}0.044 * * * \\
{[6.13]}\end{array}$ & & & & \\
\hline log.netincome & $\begin{array}{c}-0.061 * * * \\
{[5.65]}\end{array}$ & $\begin{array}{c}-0.073 * * * \\
{[5.60]}\end{array}$ & & & $\begin{array}{c}0.012 * * \\
{[2.16]}\end{array}$ & $\begin{array}{l}0.012 \\
{[0.59]}\end{array}$ \\
\hline L.log.netincome & $\begin{array}{c}0.042 * * * \\
{[3.88]}\end{array}$ & $\begin{array}{c}0.002 \\
{[0.16]}\end{array}$ & & & & \\
\hline vol & $\begin{array}{c}1.826 * * * \\
{[7.14]}\end{array}$ & $\begin{array}{c}1.606^{* * *} \\
{[6.45]}\end{array}$ & & & & \\
\hline L.vol & $\begin{array}{c}0.939 * * * \\
{[3.11]}\end{array}$ & $\begin{array}{c}2.216^{* * *} \\
{[5.17]}\end{array}$ & & & & \\
\hline marketcapitalisation & & & & & $\begin{array}{c}0.022 * \\
{[1.77]}\end{array}$ & $\begin{array}{c}0.053 * * * \\
{[3.35]}\end{array}$ \\
\hline intrate & $\begin{array}{c}0.054 * * * \\
{[6.45]}\end{array}$ & $\begin{array}{c}0.044 * * * \\
{[4.92]}\end{array}$ & $\begin{array}{l}0.002 \\
{[0.47]}\end{array}$ & $\begin{array}{l}-0.003 \\
{[0.48]}\end{array}$ & $\begin{array}{c}-0.012 * * * \\
{[2.94]}\end{array}$ & $\begin{array}{c}-0.013 * * \\
{[2.37]}\end{array}$ \\
\hline $\begin{array}{l}\text { L.intrate } \\
\text { region }\end{array}$ & $\begin{array}{c}-0.069 * * * \\
{[8.87]}\end{array}$ & $\begin{array}{c}-0.034 * * * \\
{[3.75]}\end{array}$ & & & & \\
\hline Constant & $\begin{array}{c}0.177 * * * \\
{[4.91]}\end{array}$ & $\begin{array}{c}0.981 * * * \\
{[6.18]}\end{array}$ & $\begin{array}{c}0.158 * * * \\
{[7.97]}\end{array}$ & $\begin{array}{c}1.059 * * * \\
{[27.69]}\end{array}$ & $\begin{array}{l}-0.022 \\
{[0.34]}\end{array}$ & $\begin{array}{c}0.292 \\
{[1.34]}\end{array}$ \\
\hline Observations & 8540 & 8540 & 5834 & 5834 & 931 & 931 \\
\hline R-squared & 0.79 & 0.24 & 0.75 & 0.04 & 0.81 & 0.14 \\
\hline Number of $t$ & & 1532 & & 1726 & & 219 \\
\hline
\end{tabular}

Absolute value of $t$ statistics in brackets

* significant at $10 \%$;* significant at $5 \%$;** significant at $1 \%$ 